\title{
Aboveground litter inputs determine carbon storage across soil profiles: a meta-analysis
}

\author{
Shan $\mathrm{Xu}^{1}$, Emma J. Sayer ${ }^{2,3}$, Nico Eisenhauer ${ }^{4,5}$, Xiankai Lu ${ }^{6}$, Junjian Wang ${ }^{7}$, Chengshuai Liu ${ }^{1,8^{*}}$ \\ ${ }^{1}$ Guangdong Key Laboratory of Integrated Agro-environmental Pollution Control and Management, Guangdong \\ Institute of Eco-environmental Science \& Technology, Guangzhou, 510650, China \\ 2 Lancaster Environment Centre, Lancaster University, Lancaster, LA1 4YQ \\ 3 Smithsonian Tropical Research Institute, P.O. Box 0843-03092, Balboa, Ancon, Panama, Republic of Panama \\ ${ }^{4}$ German Centre for Integrative Biodiversity Research (iDiv) Halle-Jena-Leipzig, Deutscher Platz 5e, 04103 \\ Leipzig, Germany \\ ${ }^{5}$ Institute of Biology, Leipzig University, Deutscher Platz 5e, 04103 Leipzig, Germany \\ ${ }^{6}$ South China Botanical Garden, Chinese Academy of Sciences, Guangzhou, 510070, China \\ 7 Guangdong Provincial Key Laboratory of Soil and Groundwater Pollution Control, School of Environmental \\ Science and Engineering, Southern University of Science and Technology, Shenzhen 518055, China \\ 8 State Key Laboratory of Environmental Geochemistry, Institute of Geochemistry, Chinese Academy of Sciences, \\ Guiyang, 550081, China
}

* Corresponding author (C. Liu): E-mail address: liuchengshuai@vip.gyig.ac.cn Tel: +86 85185891334

\section{Acknowledgements}

This study was financially supported by the National Natural Science Foundation of China (31901135, U1612442 and 41922056), Youth Innovation Promotion Association CAS (Y201965), the Guangdong Natural Science Foundation (Grant no. 2020A1515011257), the Science and Technology Foundation of Guangdong, China (2017BT01Z176), and the GDAS' Project of Science and Technology Development (2019GDASYL-0301002). NE acknowledges support of iDiv funded by the German Research Foundation (DFG-FZT 118, 202548816). 


\begin{abstract}
Aims Aboveground plant litter inputs are important sources of soil carbon (C). We aimed to establish how experimentally altered litter inputs affect soil $\mathrm{C}$ to 1-m depth across different ecosystems, and over different timeframes.

Methods We performed a meta-analysis of 237 studies across 248 sites worldwide to assess the influence of treatment magnitude, treatment duration, initial soil C content, and climate on the response of soil $\mathrm{C}$ to altered aboveground litter inputs.

Results Overall, soil C content was lower under litter removal, but higher under litter addition compared to controls. The effects of litter manipulation were apparent throughout the soil profile and were related to treatment magnitude. Soil C content declined markedly with increasing duration of litter removal, whereas the positive effect of litter addition attenuated over time. Cropland management practices (bare fallow or additional straw incorporation) had similar effects on soil $\mathrm{C}$ to litter removal and addition treatments.

Conclusions Our study reveals rapid and consistent changes in soil C content with altered litter inputs and provides important insights into plant residue management to enhance soil C sequestration. We highlight the need for long-term experiments, with a greater focus on the processes underpinning soil $\mathrm{C}$ storage in different ecosystems.
\end{abstract}

Keywords: litter manipulation, thinning, bare fallow, soil carbon stocks, soil profiles, metaanalysis 


\section{Introduction}

Aboveground plant inputs, such as leaf litter, are an important source of carbon (C) for soils (Swift et al. 1979; Kuzyakov 2000). Plant litter inputs have already been substantially altered by global changes such as elevated carbon dioxide $\left(\mathrm{CO}_{2}\right)$ (Finzi et al. 2001; Liu et al. 2005), warming (Raich et al. 2006), precipitation changes (Zhao and Running 2010), and atmospheric nitrogen (N) deposition (Xia and Wan 2008). Changes in plant litter inputs have motivated numerous litter manipulation experiments in different ecosystems using litter removal and litter addition treatments (Leff et al. 2012; Bowden et al. 2014; Lajtha et al. 2014a, b; Sayer and Tanner 2010). In addition, human disturbance or management in different ecosystems often alters aboveground plant litter inputs to soils, such as thinning and clear cutting in forests (He et al. 2018; Lull et al. 2020), mowing in grasslands (Belay-Tedla et al. 2009; Kitchen et al. 2009; Ma et al. 2013), residue removal or mulching and bare fallow periods in croplands (Barré et al. 2010; Meyer et al. 2017). However, such management practices not only differ in the quality and quantity of organic matter added or removed from the ecosystem but can also entail substantial soil disturbance. Although previous meta-analyses have investigated how litter manipulation, biomass harvesting, thinning, or straw incorporation affects soil C storage (Nave et al. 2010; Xu et al. 2013; James and Harrison 2016; Zhang et al. 2018; Dove et al. 2019; Mathew et al. 2017, 2020), there is still much uncertainty in our understanding of how changes in aboveground plant litter inputs will affect soil C storage. Importantly, we know very little about how soil $\mathrm{C}$ content is affected at different soil depths across ecosystems and whether the impact of treatments increases or attenuates over time. Such contextdependencies may be critical to reconcile discrepancies in the results of different experimental studies, and to assess which ecosystems are most vulnerable to, or will benefit from, altered litter inputs.

Soil $C$ storage is determined by inputs of $C$ by plants and losses of $C$ through respiration during decomposition or via erosion and leaching of dissolved organic C (Jenny 1941; Fontaine et al. 2004). Therefore, the impact of litter manipulation treatments on soil C storage in different ecosystems will depend in part on the relative importance of aboveground litter inputs for soil C storage, which differs among ecosystems, as well as litter decomposition rates (Percival et al. 2000; Cotrufo et al. 2013; Xu et al. 2018). For example, root $C$ inputs are generally regarded as more important for soil C storage in grasslands than aboveground litter 
inputs (Rasse et al. 2005), and less litter-derived C may enter soils in tropical and subtropical forests compared to temperate woodlands, because decomposition is rapid in warm humid climates (Zhang et al. 2008).

Differences in the $\mathrm{C}$ storage capacity of soils can also affect how much litter-derived $\mathrm{C}$ is incorporated (Six et al. 2002b; Zhang et al. 2008) and the capacity of soils to stabilize and store organic C inputs varies widely depending on physicochemical characteristics (Six et al. 2002). For example, weathered acidic soils may have limited C storage capacity (Campo and Merino 2016; Zech et al. 1997) and soils that already have high C content may not be able to stabilize additional organic C (Stewart et al. 2007). Hence, although declines in soil C with litter removal are expected, the capacity for different soils to sequester extra $C$ from enhanced litter inputs is less certain. Several studies found no increase in soil C concentrations after 15-20 years of doubled aboveground litter inputs in temperate forests (Crow et al. 2009; Bowden et al. 2014; Lajtha et al. 2014a), whereas the results from studies in tropical forests are inconsistent. A sizeable increase in soil $\mathrm{C}$ concentrations at $0-10 \mathrm{~cm}$ depth in the mineral soil after two years of double litter inputs to small plots in Costa Rica (Leff et al. 2012) may be partly explained by increased root growth in response to the nutrients added with the litter. However, although soil $\mathrm{C}$ concentrations at $0-5 \mathrm{~cm}$ depth had increased by $32 \%$ after 11 years of double litter inputs in large-scale plots in Panama (Cusack et al. 2018), there were no changes in soil C stocks or concentrations at greater soil depths $(0-10,10-20$, or $20-30 \mathrm{~cm})$, even after 15 years of litter addition (Sayer et al. 2019). Mineral and physical protection of $\mathrm{C}$ in soils may also determine whether soil $\mathrm{C}$ concentrations continue to decline with litter removal over time. Hence, changes in soil $\mathrm{C}$ stocks and concentrations with altered aboveground litter inputs likely depend greatly on soil $\mathrm{C}$ storage capacity and treatment duration, and an assessment of temporal patterns of change in soil $\mathrm{C}$ with litter manipulation can improve our understanding of soil $\mathrm{C}$ sequestration in response to changes in plant litter inputs.

Finally, the influence of litter removal or addition treatments on soil C pools is likely to decline with depth. The surface layers of mineral soil are in direct contact with the organic horizon, which is largely formed from aboveground litter inputs, and hence, the topsoil is considered to be more sensitive to variations in litterfall (Harrison et al. 2011; Xu et al. 2013). However, aboveground litter inputs can also affect $\mathrm{C}$ storage in deeper soil horizons, as dissolved organic carbon (DOC) released by leaching and decomposition processes percolates 
down the soil profile (Kaiser and Kalbitz 2012; Liebmann et al. 2020). Although DOC represents an important pathway for C inputs to the subsoil (Kalbitz and Kaiser 2008; Liebmann et al. 2020), litter-derived DOC can also cause priming effects, which stimulate the mineralization of extant $C$, and could offset increases in soil $C$ concentrations in deeper soil horizons (Chen et al. 2019). To date, the effects of aboveground litter inputs on soil C storage through the soil profile remain poorly characterized, especially for subsoil horizons (i.e. >20 cm depth), which contain more than $50 \%$ of global soil C stocks (Rumpel et al. 2012).

Not only are the effects of altered litter inputs highly variable across soils and ecosystems, but we lack a comprehensive assessment of how soil C changes in response to altered litter inputs at different soil depths or on different timescales. However, general responses of soil $\mathrm{C}$ content to altered litter inputs can be predicted by a simple mass balance equation, in which changes in soil $\mathrm{C}$ storage over time are the result of $\mathrm{C}$ inputs by plants minus losses of $\mathrm{C}$ during decomposition (Jenny 1941; Fontaine et al. 2004). If the C storage capacity of soils is limited, they will eventually become C-saturated, which will constrain the response to additional litter inputs (Stewart et al. 2007). Accordingly, we hypothesised that:

$\mathrm{H} 1)$ Soil C content and stocks will increase with litter addition and decline with litter removal, with greater effects on soil C storage in topsoil $(0-20 \mathrm{~cm})$ than in subsoil $(20-100 \mathrm{~cm})$;

$\mathrm{H} 2$ ) The magnitude of change in soil $\mathrm{C}$ in response to altered litter inputs will increase with litter input level and the duration of treatments.

$\mathrm{H} 3$ ) The increase in soil $\mathrm{C}$ with litter addition will be greatest in soils with low initial soil $\mathrm{C}$ content but declines in soil $\mathrm{C}$ with litter removal will be greater in soils with high initial soil C content.

To test these hypotheses, we performed a meta-analysis of 237 studies, in which aboveground litter inputs were experimentally manipulated or altered by management practices. We assessed the influence of litter manipulation on soil C storage at multiple soil depths across ecosystems, and also assessed the influence of climate to explain differences in effects among ecosystems. In addition, we determined how common management practices (forest thinning, grassland mowing, and straw incorporation in croplands; Fig. 1) might affect soil $\mathrm{C}$ by altering aboveground plant litter inputs. 


\section{Materials and methods}

\section{Data selection}

We searched for studies that altered aboveground litter inputs and measured their effects on soil C content or stocks. Although many litter manipulation studies have been conducted since the first experiments in the 1850s, very few of the early studies report changes in soil C content or stocks (Sayer 2006; Xu et al. 2013). Therefore, we first conducted a comprehensive search of relevant peer-reviewed articles and dissertations in the Web of Science ${ }^{\circledast}$ and ProQuest databases using combinations of the following search string: ("litter removal" OR "no litter" OR "decreased litter" OR "clipping" OR "mowing" OR "straw harvesting" OR "thinning" OR "bare fallow" OR "litter manipulation" OR "litterfall manipulation" OR "leaf litter manipulation" OR "organic matter manipulation" OR "detritus manipulation" OR "carbon input manipulation" OR "altered aboveground litter inputs" OR "alterations in forest detritus inputs" OR "increased litter" OR "litter addition" OR "double litter" OR "straw incorporation") AND ("soil carbon" OR "soil organic carbon" OR "soil characteristics"). We cross-checked the references of the articles to identify other relevant book chapters and peerreviewed reports, resulting in 237 studies across 248 sites. In addition to litter manipulation experiments (litter removal and litter addition treatments), we further classified straw harvesting and residue removal in cropland as "litter removal", straw mulching with the equivalent of annual aboveground litter production as controls (e.g. Akhtar et al. 2018b; Wang et al. 2019), but straw mulching in excess of the annual aboveground litter production as "litter addition" (e.g. de Abreu Sousa Junior et al. 2018; Zhang et al. 2015a). As we aimed to assess the influence of aboveground plant litter on soil C storage, we only included results for crop residue management that were comparable with litter manipulation treatments in other ecosystems. We thus excluded the results of manure, fertilizer or plastic mulch applications, as well as studies focusing only on the effect of crop rotations or the type of cover crops on soil C storage. It is also important to note that although management practices such as thinning in forests, mowing in grasslands, and bare fallow or straw incorporation in cropland alter aboveground plant inputs, they can also directly affect belowground $\mathrm{C}$ inputs by altering fine root biomass (Asaye and Zewdie 2013) or cause substantial soil disturbance, and thus we analyzed their effects separately (Fig. 1). 
We extracted data for total soil C or soil organic C content (given as $\%$ or $\mathrm{g} \mathrm{kg}^{-1}$ ) and stocks (given as $\mathrm{g} \mathrm{m}^{-2}, \mathrm{~kg} \mathrm{~m}^{-2}$ or $\mathrm{Mg} \mathrm{ha}^{-1}$ ) in topsoil (i.e. the upper $20 \mathrm{~cm}$ of mineral soil), which included four individual depth increments most commonly measured across studies $(0-5 \mathrm{~cm}$, 5-20 cm, 0-10 cm, 0-20 cm), and subsoil (i.e. 20-100 cm depth). We also obtained data for mean annual temperature (MAT, ${ }^{\circ} \mathrm{C}$ ), mean annual precipitation (MAP, $\mathrm{mm}$ ), treatment level ( $g$ dry mass $\mathrm{m}^{-2} \mathrm{yr}^{-1}$ or $\mathrm{g} \mathrm{C} \mathrm{m}^{-2} \mathrm{yr}^{-1}$ ), and treatment duration (number of years). If the paper gave the treatment level as $\mathrm{g} \mathrm{C} \mathrm{m}^{-2} \mathrm{yr}^{-1}$, we multiplied the value by two to convert it to $\mathrm{g}$ dry mass. We collated data from the main text, tables, and figures. We converted all soil $\mathrm{C}$ data to the same unit ( $\mathrm{g} \mathrm{kg}^{-1}$ for soil $\mathrm{C}$ content, and $\mathrm{kg} \mathrm{m}^{-2}$ for soil $\mathrm{C}$ stocks), and numerical values from graphically presented data were extracted by digitizing the figures using Engauge Digitizer (Free Software Foundation, Inc., Boston, USA).

The ecosystems in our dataset included grassland, plantation, natural forest and cropland. For natural forest, we grouped "subtropical forest" and "tropical forest" together into "tropical forest" and thus, natural forests included boreal forest, temperate forest and tropical forest. The experimental sites included in our study are shown in Figure S1, which was generated using R version 3.5.1 (R Development Core Team 2018) using the packages ggsn (Baquero 2017) and legendMap (Gallic 2016). The full dataset is provided in the supplementary information.

\section{Meta-analysis}

All statistical analyses were conducted in R versioin 3.5.1 ( $R$ Development Core Team 2018). To test our first two hypotheses we conducted a metaanalysis using the "metafor" package (Viechtbauer 2010). The data were analyzed using effect sizes for each observation calculated as the natural $\log$ of the response ratio (RR): $\mathrm{RR}=\ln \left(\overline{X_{t}} / \overline{X_{c}}\right)$, where $\overline{X_{c}}$ is the control mean, i.e. data from plots receiving natural litterfall, and $\overline{X_{t}}$ is the treatment mean, i.e. data from plots receiving no litter inputs or added litter inputs. Effect sizes and variances were calculated using random-effects models with restricted maximum-likelihood estimators (Viechtbauer 2005), which allows for sampling error and cross-study variability in true effect sizes (Viechtbauer 2005; Borenstein et al. 2012). Effects were significant if bootstrap confidence intervals (Cls) did not overlap with zero (Collins et al. 1985; van den Noortgate et al. 2005). We then ran standard meta-analyses to test the total heterogeneity of effect sizes 
within each model whereby $P$ values $<0.05$ indicated heterogeneity in effects between studies when accounting for sampling error (Koricheva et al. 2013). To identify differences in the magnitude of effects among ecosystem types, we subsequently conducted a subgroup analysis for each parameter. We present results for separate ecosystems only where at least three observations were available in more than one subgroup. However, the results were considered valid when there were at least four observations (Fu et al. 2011). Total heterogeneity $\left(Q_{T}\right)$ was partitioned into within-group $\left(Q_{W}\right)$ and between-group $\left(Q_{B}\right)$ heterogeneities, whereby a significant $Q_{B}$ indicates significant differences among groups (Hedges et al. 1999) and group means were considered significantly different if their 95\% confidence intervals did not overlap. The publication bias was estimated by the dnorm function (Fig. S1 in the Supplement A), and the frequency distributions of all RR values for the target variables followed a normal distribution, indicating an absence of publication bias in our study (Koricheva and Gurevitch 2014). As one of our aims was to assess the influence of treatment duration on soil $C$ concentrations, we included RR values for multiple timepoints within some studies, and we accounted for this non-independence of observations using study ID nested in site ID (site/study) as a random factor in each of the models.

\section{Regression analysis of potential modulators}

To test our second hypothesis, we first used linear and non-linear regression analyses to assess the influence of treatment level, treatment duration, climate, and initial soil C content on the response (RR) of soil $C$ content to litter removal and litter addition treatments (excluding thinning, mowing, bare fallow and straw incorporation) across soil profiles. Given the large differences in aboveground litter inputs among ecosystem types, we analyzed the relationships separately for cropland and forested ecosystems (including natural forest and plantations), but insufficient data were available for grassland. To assess the influence of treatment level, we used aboveground litter inputs (in g dry mass $\mathrm{m}^{-2} \mathrm{yr}^{-1}$ ) as treatment levels, whereby litter removal and addition treatments were considered as negative or positive litter inputs, respectively. We then assessed changes in soil C over time using treatment duration (in years) across all ecosystems. We also separately analyzed the influence of treatment duration on the RR of soil C content for thinning in forest and bare fallow in cropland, but insufficient data were available for mowing in grassland. We assessed the influence of climate on the response of soil $\mathrm{C}$ content to litter manipulation treatments using a humidity index, i.e. 
the ratio of mean annual precipitation $(M A P)$ to mean annual potential evapotranspiration (MAP/PET), for each site (Zhou et al. 2015). Annual PET was estimated using Hamon's method using the methodology described by Zhou et al. (2019).

$$
P E T=0.1651 \times D \times V_{d} \times K \times 365
$$

where $D$ is the time from sunrise to sunset in multiples of $12 \mathrm{~h}$, which varies with date, latitude, slope and aspect of a watershed (if the influences of slope and aspect are not considered, the average daily $\mathrm{D}$ of an entire year is 1 ); $V_{d}$ is the saturated vapour density ( $g$ $\left.\mathrm{m}^{-3}\right)$ at the annual mean temperature $\left(\mathrm{T} ;{ }^{\circ} \mathrm{C} ; \mathrm{K}\right.$ is the correction coefficient to adjust $P E T$ calculated using Hamon's method to realistic values, which range from 1.2 to 1.4. Thus, for consistency, we used $K=1.3$ to calculate the $P E T$ s at all sites.

Finally, we evaluated the evidence for our third hypothesis of soil C saturation from the relationship between initial soil $C$ content $\left(\mathrm{g} \mathrm{kg}^{-1}\right)$ and the $\mathrm{RR}$ of soil $\mathrm{C}$ content under litter removal and litter addition treatments. We used linear mixed models (Imer function in the Ime4 package, Bates et al. 2015) to analyze how experimental duration, initial soil C content and MAP/PET affect the responses of soil C content to litter removal and litter addition. We fitted experimental duration, initial soil $\mathrm{C}$ content and MAP/PET as fixed factors, and ecosystem type and site as random factors. We calculated $P$-values for individual terms using Satterthwaite approximation (ImerTest package, Kuznetsova et al. 2015). The overall model fit was assessed by comparison to the appropriate null model using a likelihood ratio test. For all analyses, we report significant effects relative to control treatments (i.e. where RR differs significantly from zero) at $P \leq 0.05$ and marginally significant trends at $0.05<P<0.1$

\section{Results}

\section{Changes in soil $C$ contents and stocks with depth}

Overall, there was a significant decline in soil $\mathrm{C}$ content and stocks with litter removal at all measured depth increments $(0-5 \mathrm{~cm}, 5-20 \mathrm{~cm}, 0-10 \mathrm{~cm}, 0-20 \mathrm{~cm}$ and $20-100 \mathrm{~cm}$ ) (Fig. 2a) and a significant increase in soil $\mathrm{C}$ content with litter addition at all measured depth increments (Fig. 2b) but there was no response of soil $\mathrm{C}$ stocks to litter addition at any soil depth across all ecosystems (Fig. 2b). 
When data were partitioned into different ecosystems, we observed a significant decrease in soil C content with litter removal at $0-20 \mathrm{~cm}$ in grassland and at $0-5 \mathrm{~cm}, 5-20 \mathrm{~cm}$, 0-10 cm and 0-20 cm in natural forest (Fig. 3a). However, litter removal had no significant effect on soil C content at other soil depths in grassland or at $20-100 \mathrm{~cm}$ in natural forest (Fig. 3a). In plantations, there was no effect of litter removal on soil C content at $0-5 \mathrm{~cm}, 5-20 \mathrm{~cm}$ or 20-100 cm depth, but soil C content was significantly lower with litter removal at 0-10 cm and 0-20 cm (Fig. 3a). Similarly, in croplands there was no effect of bare fallow at 0-5 cm but lower soil C content at 5-20 cm, 0-10 cm, 0-20 cm and 20-100 cm (Fig. 3a). In response to litter addition treatments in grasslands, we observed higher soil $\mathrm{C}$ content at $0-5 \mathrm{~cm}$ and a marginally significant increase at $0-20 \mathrm{~cm}$ (Fig. 3b). In natural forest, soil C content was significantly higher at $5-20 \mathrm{~cm}$ and $0-10 \mathrm{~cm}$ with litter addition, and there was a marginally significant trend towards higher soil C content at $0-5 \mathrm{~cm}$ and $0-20 \mathrm{~cm}$ (Fig. 3b), but there was no effect of litter addition at 20-100 cm (Fig. 3b). Finally, in plantations and cropland soil C content at 20-100 cm was significantly higher with litter addition but there was no effect of litter addition on soil $\mathrm{C}$ content at other depths (Fig. 3b).

Soil C stocks were significantly lower with litter removal at $0-10 \mathrm{~cm}$ in grassland, $0-5 \mathrm{~cm}$ and $0-10 \mathrm{~cm}$ in forest, $0-5 \mathrm{~cm}, 5-20 \mathrm{~cm}, 0-20 \mathrm{~cm}$ and $20-100 \mathrm{~cm}$ in cropland, but were only marginally lower at $5-20 \mathrm{~cm}$ in plantations and $0-10 \mathrm{~cm}$ in cropland (Table 1). Litter addition did not affect soil $\mathrm{C}$ stocks in any ecosystem (Table 1 ).

Separate assessment of temperate and tropical forest showed that soil $\mathrm{C}$ content was lower with litter removal at $0-5 \mathrm{~cm}, 0-10 \mathrm{~cm}, 0-20 \mathrm{~cm}$ and $20-100 \mathrm{~cm}$ in temperate forest but only at $0-5 \mathrm{~cm}, 5-20 \mathrm{~cm}$ and $0-10 \mathrm{~cm}$ in tropical forest (Fig. S3a). Data for soil C stocks were not consistently available across ecosystems, treatments or depth increments. However, soil C stocks were significantly lower with litter removal at 0-10 $\mathrm{cm}$ in temperate forest and at 0$5 \mathrm{~cm}$ in tropical forest (Fig. S3a). By contrast, with litter addition, soil C stocks were significantly lower at $20-100 \mathrm{~cm}$ in temperate forest but higher at $5-20 \mathrm{~cm}$ in tropical forest (Fig. S3b).

The effects of management practices that alter aboveground litter inputs on soil $\mathrm{C}$ content and stocks in forests, grassland and cropland were highly variable. In response to forest thinning, soil $C$ content at $0-10 \mathrm{~cm}$ and soil $C$ stocks at $5-20 \mathrm{~cm}$ and $0-10 \mathrm{~cm}$ were significantly higher, whereas soil C content and stocks at other soil profiles were not affected 
(Fig. S4a,b). Mowing in grasslands had no effect on soil C content or stocks at any depth (Fig. S4a,b). In response to bare fallow in cropland, there topsoil C content was lower at 0-10 cm and $0-20 \mathrm{~cm}$, but subsoil $\mathrm{C}$ content was unaffected (Fig. S4a). Soil C stocks at $0-20 \mathrm{~cm}$ were also significantly lower under bare fallow (Fig. S4b), but there were insufficient data to assess changes at other depth increments. By contrast, soil C content in cropland was significantly higher at all soil depths with additional straw incorporation (Fig. S4c).

\section{Modulators of soil C content responses to litter manipulation across soil profiles}

Regression analysis showed that the response (RR) of forest soil $C$ content to litter manipulation increased linearly with treatment level at $0-5 \mathrm{~cm}, 5-20 \mathrm{~cm}, 0-10 \mathrm{~cm}$ and $0-20 \mathrm{~cm}$ depth (Fig. 4c, d, e, f), indicating that both litter removal and addition had similar substantial effects on soil $\mathrm{C}$ in forests.

Across all ecosystems, the response ratios of soil C content with litter removal at $5-20 \mathrm{~cm}$ and $0-10 \mathrm{~cm}$ were marginally significantly related to treatment duration, becoming more negative over time (Fig. 5b,c, Table S2). The response ratio of soil C content with litter addition first increased and then decreased with treatment duration at 0-5 cm (Fig. 5a), but the declined significantly with treatment duration at $0-20 \mathrm{~cm}$ and $20-100 \mathrm{~cm}$ (Fig. $5 \mathrm{~d}$,e, Table S2). The influence of climate on the effect size of litter manipulation treatments was limited to surface soils, as only the changes in soil $\mathrm{C}$ content at $0-20 \mathrm{~cm}$ declined significantly with MAP/PET (Fig. 6d, Table S2). However, the response ratio of soil C content with litter addition at $5-20 \mathrm{~cm}$ and $20-100 \mathrm{~cm}$ was significantly related to initial soil C content (Fig. S6b,e, Table S2).

\section{Discussion}

Our meta-analysis demonstrates that soil C content and stocks were generally lower in litter removal and that soil $\mathrm{C}$ content was higher with litter addition throughout the soil profile across multiple ecosystems. The effect of litter manipulation treatments on C content in the upper $20 \mathrm{~cm}$ of forest soils generally increased with treatment level (i.e. the amount of litter added or removed), but there were substantial differences in the magnitude of treatment effects among ecosystems. Crop residue management (bare fallow and additional straw incorporation) had analogous effects on soil C content and stocks to litter removal and 
addition treatments, respectively, whereas the effects of forest thinning and grassland mowing were inconsistent. Although the gradual decline in soil $\mathrm{C}$ content with litter removal over time emphasizes the importance of aboveground litter inputs for soil C storage, the lack of substantial increases in soil $\mathrm{C}$ in response to long-term litter addition treatments also demonstrates that many soils have limited capacity to sequester additional plant-derived C.

\section{Responses of soil C content and stocks to altered aboveground litter inputs across soil depths}

We demonstrate that litter manipulation treatments and land management such as thinning in forest (He et al. 2018; Lull et al. 2020), mowing in grassland (Belay-Tedla et al. 2009; Kitchen et al. 2009; Ma et al. 2013), and bare fallow in cropland (Barré et al. 2010; Meyer et al. 2017), can alter soil $\mathrm{C}$ storage, but the depth to which changes were apparent depended on the treatment or management practice. Our comparison of changes across depth increments was somewhat hampered by the lack of standard sampling depths among ecosystems. Although soils were sampled at $0-5 \mathrm{~cm}$ in all ecosystems, grassland soils were most commonly sampled at $0-20 \mathrm{~cm}$, forest soils at $0-10 \mathrm{~cm}$, and croplands at $0-20 \mathrm{~cm}$ (Fig. 3). Nonetheless, our metaanalysis showed an overall decline in soil C content with litter removal and an increase in soil C content with litter addition at all soil depths (Fig. 2a), which lends some support to our first hypothesis. The effects of litter removal on soil C content were generally most apparent at the soil surface, which expands upon the findings of individual studies demonstrating limited changes below $10-\mathrm{cm}$ depth, even after more than a decade of litter manipulation treatments (Xu et al. 2013; Tanner et al. 2016; Kitchen et al. 2009; Sayer et al. 2019). Declining effects of litter removal on subsoil $\mathrm{C}$ content $(>20 \mathrm{~cm})$ were hypothesized because aboveground litter inputs are probably not the main source of $C$ input to deeper soil horizons (Fröberg et al. 2007), where root inputs, such as rhizodeposits and root litter, or microbial residues are a more important source of C (Angst et al. 2016, 2018). Accordingly, isotope labeling studies demonstrate that recovery of litter-derived $\mathrm{C}$ declines markedly with soil depth in natural ecosystems (Table S1, Fig. S7; Cotrufo et al. 2015). However, the significant increase in subsoil C content with litter addition across all ecosystems is surprising (Fig. 2 b) and can be largely attributed to changes in subsoil C content in cropland and plantations (Fig. 3b), where soil disturbance or compaction may affect the measured changes in subsoil $\mathrm{C}$ content.

Responses of soil C content and stocks to altered aboveground litter inputs across ecosystems 
Although it is widely accepted that aboveground litter inputs are important $\mathrm{C}$ sources for soils across terrestrial ecosystems, our results showed that the magnitude of change in soil C content and stocks with litter manipulation differed among ecosystem types (Fig. 3; Table 1). The greater decline in surface soil $\mathrm{C}$ content at $0-5 \mathrm{~cm}$ in natural forest compared to other ecosystems (Fig. 3) highlights the importance of leaf litter inputs for maintaining soil C pools in forests (Bowden et al. 2014). By contrast, the lack of changes in surface soil C content with litter removal in grasslands (Fig. 3) might be explained by the greater contribution of roots to soil organic C (Rasse et al. 2005), and the importance of photodegradation as a litter decomposition pathway in grasslands, resulting in relatively lower litter-derived $\mathrm{C}$ inputs to soils (Austin and Vivanco 2006; Brandt et al. 2007). However, despite distinct decomposition processes and the greater relative importance of root $\mathrm{C}$ inputs in grasslands, topsoil $\mathrm{C}$ content $(0-20 \mathrm{~cm})$ was clearly affected by aboveground litter removal and addition treatments (Fig. 3).

The declines in topsoil C content with litter removal were particularly strong in forests, especially at the soil surface (Fig. 3), and were related to treatment duration in both temperate forests and tropical forests (Fig. S8a,b). However, it is noteworthy that the effects of litter removal were greater and much more consistent than the effects of litter addition (Fig. 3). Although the overall response of soil C to litter manipulation was similar in temperate and tropical forests (Fig. S3), the changes in soil C with duration of litter addition treatments differed between forest ecosystems. In temperate forests, the changes in soil C content at 0$10 \mathrm{~cm}$ increased marginally with increasing treatment duration (Fig. S8c), whereas in tropical forests, only soil $\mathrm{C}$ content at $0-5 \mathrm{~cm}$ increased during the first 10 years of litter addition (Fig. S8d). Although tropical forest soils are generally not regarded as C-saturated (Gulde et al. 2008; Castellano et al. 2015; Hedin 2015), C loss by priming effects may offset the additional litter-derived C inputs (Sayer et al. 2011, 2019). In addition, the differences between temperate and tropical forests indicate that rapid decomposition in the tropics could reduce the amount of litter-derived $C$ entering the soil, requiring longer-term studies to detect measurable changes in soil $\mathrm{C}$ below the top $5-\mathrm{cm}$. The weak relationship between soil $\mathrm{C}$ and treatment duration in temperate forests could indicate greater influence of dominant tree species or substantial differences in soil types and soil C storage capacity in temperate forests (Bowden et al. 2014; Fekete et al. 2014; Lajtha et al. 2014b). Indeed, a recent study demonstrated marked differences in soil $\mathrm{C}$ storage between temperate forests dominated by 
trees with arbuscular vs. ectomycorrhizal associations and a strong link between $\mathrm{C}$ storage capacity and nitrogen availability (Cotrufo et al. 2019).

Changes in soil $\mathrm{C}$ storage in plantations are important because they make up approximately $5 \%$ of the world's forest cover (FAO 2010). We found that soil C content in plantations decreased with litter removal to a similar extent as in grasslands, but we observed no change in topsoil $\mathrm{C}$ content with litter addition (Fig. 3). The response of soil $\mathrm{C}$ to altered litter inputs is probably largely determined by the tree species grown in each plantation. For example, Wang et al. (2019) found that doubling aboveground litter inputs significantly increased soil $\mathrm{C}$ content and metabolism of labile $\mathrm{C}$ in oak plantations but not in pine plantations. In addition, plantation management practices will strongly influence the response of soil $\mathrm{C}$ to changes in litter inputs, for example, by altering soil nutrient availability (Zhao et al. 2017), via straw harvesting (Blazier et al. 2008) or thinning (Jandl et al. 2007).

Forest thinning did not have consistent effects on soil $\mathrm{C}$ content across the soil profile, which can be attributed to changes in other ecosystem and soil properties as a result of management practices. For example, forest thinning can reduce aboveground litterfall for several years, but thinning also results in large inputs of residues (Jandl et al. 2007) and increases fine root biomass (Asaye and Zewdie 2013; Wang et al. 2019), which may compensate for the loss of litter inputs. The impact of thinning on soil $\mathrm{C}$ storage also varies strongly depending on the intensity and the length of thinning intervals (Jandl et al. 2007), which may explain why we found no relationship between treatment duration and the magnitude of thinning effects on topsoil C content (Fig. S9a,b,c,d).

The importance of crop residue management for soil $C$ storage in croplands is demonstrated by the strong declines in soil $\mathrm{C}$ content and stocks across the soil profile in response to bare fallow treatments (Fig. S4a,b), which intensified with treatment duration (Fig. S10). The corresponding increases in cropland soil C content with additional incorporation of straw (Fig. S4c) highlight the importance of plant C inputs for current goals to increase $C$ sequestration in agricultural soils (Lal et al. 2016). However, we note that our analysis only included crop residue management comparable to litter manipulation treatments, and other agricultural management practices, such as manure application, crop rotation and different cover crops, also have a substantial influence on soil C storage (see reviews by Ugarte et al. 2014 and Bolinder et al. 2020). 


\section{Regulators of changes in soil C content}

Our regression analyses revealed that treatment level, duration, climate and initial soil C content influenced the magnitude of changes in soil $\mathrm{C}$ content to altered aboveground litter inputs. By assessing the effects of litter removal and litter addition treatments as a continuous variable based on aboveground litter inputs, we show that the response of soil $C$ content generally increased with treatment level at most depths in forests (Fig. 4), which provides evidence in support of our second hypothesis. Our results expand the findings of Xu et al. (2013) to demonstrate that the impact of litter manipulation extends through the soil profile and emphasize the importance of litter quantity for soil $\mathrm{C}$ accumulation.

We further hypothesized that the response of soil $\mathrm{C}$ to litter manipulation treatments would become more pronounced with experimental duration. In line with our second hypothesis, we observed a continual decline in soil C content with increasing duration of litter removal treatments (Figs. 5,S7, Table S2), which was most pronounced in bare fallow treatments in cropland, which also excludes root C inputs (Paterson et al. 2011; Fig. S10). By contrast, soil $\mathrm{C}$ content did not continue to increase with the duration of litter addition treatments, except at the soil surface $(0-5 \mathrm{~cm})$, and subsoil $\mathrm{C}$ content even tended to decline with long-term litter addition (Fig. 5). The lack of a consistent increase in soil C content with litter addition can be attributed to two distinct mechanisms: First, priming effects as a result of increased inputs of labile organic compounds and fluxes of DOC into deep soil profiles could offset some of the $\mathrm{C}$ gains from added plant material (Fontaine et al. 2007; Hofmockel et al. 2011; Lajtha et al. 2018; Sayer et al. 2011, 2019). Second, many of the soils at the study sites may have a limited capacity to sequester additional $C$ inputs because they already had high initial $\mathrm{C}$ content, or possibly because soil $\mathrm{C}$ storage is constrained by available binding sites (Six et al. 2002a) or nitrogen availability (Cotrufo et al. 2019). Limited additional soil C storage capacity at many of the sites included in our study is apparent in the negative relationship between initial soil $\mathrm{C}$ content and the response ratio of soil $\mathrm{C}$ content to litter addition (Fig. S6), which supports our third hypothesis of soil C saturation (Six et al. 2002a; Stewart et al. 2007; Xu et al. 2018). Based on the general patterns detected by our meta-analysis, we also speculate that other factors (e.g., litter quality, nitrogen availability, and soil structure) influence the capacity of soils to respond to altered litter inputs (Bowden et al. 2014; Cotrufo et al. 2019; Zhou et al. 2019; Sayer et al. 2020), which merits further study in the future. 


\section{Conclusions}

Our meta-analysis demonstrates that soil C content and stocks decreased with litter removal, and soil C content, but not stocks, increase with litter addition, and that the changes were detectable across ecosystems and through the soil profile to 1-m depth. The increasing response ratio of soil $\mathrm{C}$ content with treatment level suggests that aboveground plant $\mathrm{C}$ inputs are crucial for soil $\mathrm{C}$ sequestration in both managed and unmanaged systems. However, our results also indicate that many soils have limited capacity to store additional $C$ inputs, especially in unmanaged ecosystems.

\section{Author contributions}

CSL and SX designed this study. SX searched the papers, collected and analyzed the data. SX and EJS wrote the paper. All authors contributed to interpretation and commented on the details of the manuscript drafts.

\section{Conflict of Interest}

The authors declare that they have no conflict of interest.

\section{Data availability}

The data set used for the meta-analysis will be made available after acceptance. 


\section{References}

Adams DC, Gurevitch J, Rosenberg MS (1997) Resampling tests for meta-analysis of ecological data. Ecology 78:1277-1283

Angst G, Heinrich L, Kögel-Knabner I, Mueller CW (2016) The fate of cutin and suberin of decaying leaves, needles and roots-Inferences from the initial decomposition of bound fatty acids. Org Geochem 95:81-92

Angst G, Messinger J, Greiner M et al (2018) Soil organic carbon stocks in topsoil and subsoil controlled by parent material, carbon input in the rhizosphere, and microbial-derived compounds. Soil Biol Biochem 122:19-30

Asaye Z, Zewdie S (2013) Fine root dynamics and soil carbon accretion under thinned and unthinned Cupressus lusitanica stands in, Southern Ethiopia. Plant Soil 366:261-271

Austin AT, Vivanco L (2006) Plant litter decomposition in a semi-arid ecosystem controlled by photodegradation. Nature 442:555-558

Baquero OS (2017) ggsn: North Symbols and Scale Bars for Maps Created with 'ggplot2' or 'ggmap'. Available at https://CRAN.R-project.org/package=ggsn

Barré $P$, Eglin T, Christensen BT, Ciais P, Houot S, Kätterer T, van Oort F et al. (2010) Quantifying and isolating stable soil organic carbon using long-term bare fallow experiments. Biogeosciences 7:3839-3850

Bates D, Mächler M, Bolker BM, Walker SC (2015) Fitting linear mixed-effects models using Ime4. J Stat Softw 67

Belay-Tedla A, Zhou X, Su B, Wan S, Luo Y (2009) Labile, recalcitrant, and microbial carbon and nitrogen pools of a tallgrass prairie soil in the US Great Plains subjected to experimental warming and clipping. Soil Biol Biochem 41:110-116

Blazier MA, Patterson WB, Hotard SL (2008) Straw harvesting, fertilization, and fertilizer type alter soil microbiological and physical properties in a loblolly pine plantation in the midsouth USA. Biol Fert Soils 45:145-153

Bolinder MA, Crotty $\underline{E}$, Elsen $\underline{A}$ et al (2020) The effect of crop residues, cover crops, manures and nitrogen fertilization on soil organic carbon changes in agroecosystems: a synthesis of reviews. Mitig Adapt Strat GI 25:929-952

Borenstein M, Hedges LV, Higgins J, Rothstein H (2012) Introduction to meta-analysis. Chichester, UK: John Wiley \& Sons.

Bowden RD, Deem L, Plante AF, Peltre C, Nadelhoffer K, Lajtha K (2014) Litter input controls on soil carbon in a temperate deciduous forest. Soil Sci Soc Am J 78:S66-S75

Brandt JB, Sulzman EW, Myrold DD (2007) Microbial community utilization of added carbon substrates in response to long-term carbon input manipulation. Soil Biol Biochem 38:2219-2232

Campo J, Merino A (2016) Variations in soil carbon sequestration and their determinants along a precipitation gradient in seasonally dry tropical forest ecosystems. Glob Chang Biol 22:1942-1956 
Castellano MJ, Mueller KE, Olk DC, Sawyer JE, Six J (2015) Integrating plant litter quality, soil organic matter stabilization, and the carbon saturation concept. Glob Chang Biol 21:3200-3209

Chen L, Liu L, Qin S et al (2019) Regulation of priming effect by soil organic matter stability over a broad geographic scale. Nat Commun 10:5112

Collins R, Yusuf S, Peto R. (1985) Overview of randomised trials of diuretics in pregnancy. British Medical Journal 290:17-23.

Cotrufo MF, Ranalli MG, Haddix ML et al (2019) Soil carbon storage informed by particulate and mineral-associated organic matter. Nat Geosci 12:989-994.

Cotrufo MF, Soong JL, Horton AJ et al (2015) Formation of soil organic matter via biochemical and physical pathways of litter mass loss. Nat Geosci 8:776-779

Cotrufo MF, Wallenstein MD, Boot CM, Denef K, Paul E (2013) The Microbial Efficiency-Matrix Stabilization (MEMS) framework integrates plant litter decomposition with soil organic matter stabilization: do labile plant inputs form stable soil organic matter? Glob Change Biol 19:988-995

Crow SE, Lajtha K, Filley TR, Swanston CW, Bowden RD, Caldwell BA (2009) Sources of plantderived carbon and stability of organic matter in soil: implications for global change. Glob Change Biol 15:2003-2019

Cusack DF, Halterman SM, Tanner EVJ et al (2018) Decadal-scale litter manipulation alters the biochemical and physical character of tropical forest soil carbon. Soil Biol Biochem 124:199-209

de Martonne E (1926) Une nouvelle fanction climatologique: I'indice d'aridite. La Meteorologie, 2, 449-458

Dove NC, Stark JM, Newman GS, Hart SC (2019) Carbon control on terrestrial ecosystem function across contrasting site productivities: the carbon connection revisited. Ecology https://doi.org/10.1002/ecy.2695

FAO (2010) Global Forest Resources Assessment. FAO Forestry Paper 163, Food and Agriculture Organization of the United Nations, Rome, Italy

Fekete I, Kotroczó Z, Varga C, Nagy PT, Tóth JA, Bowden RD et al (2014) Alterations in forest detritus inputs influence soil carbon concentration and soil respiration in a CentralEuropean deciduous forest. Soil Biol Biochem 74:106-114

Finzi AC, Allen AS, DeLucia EH, Ellsworth DS, Schlesinger WH (2001) Forest litter production, chemistry, and decomposition following two years of free-air $\mathrm{CO} 2$ enrichment. Ecology 82:470-484

Fontaine S, Bardoux G, Abbadie L, Mariotti A (2004) Carbon input to soil may decrease soil carbon content. Ecol Lett 7:314-320

Fontaine S, Barot S, Barre P, Bdioui N, Mary B, Rumpel C (2007) Stability of organic carbon in deep soil layers controlled by fresh carbon supply. Nature 450:277-80

Fröberg M, Jardine PM, Hanson PJ et al (2007) Low dissolved organic carbon input from fresh litter to deep mineral soils. Soil Sci Soc Am J 71:347 
Fu R, Gartlehner G, Grant M et al (2011) Conducting quantitative synthesis when comparing medical interventions: AHRQ and the Effective Health Care Program. J Chronic Dis 64:1187-1197

Gallic E (2016) legendMap: North arrow and scale bar for ggplot2 graphics. R package version 1.0

Gulde S, Chung H, Amelung W, Chang C, Six J (2008) Soil carbon saturation controls labile and stable carbon pool dynamics. Soil Sci Soc Am J 72:605

Harrison RB, Footen PW, Strahm BD (2011) Deep soil horizons: contribution and importance to soil carbon pools and in assessing whole-ecosystem response to management and global change. For Sci 57:67-76

He ZB, Chen LF, Du J, Zhu X, Lin PF, Li J, Xiang YZ (2018) Responses of soil organic carbon, soil respiration, and associated soil properties to long-term thinning in a semiarid spruce plantation in northwestern China. Land Degrad Dev. 1-10

Hedges LV, Gurevitch J, Curtis PS (1999) The meta-analysis of response ratios in experimental ecology. Ecology 80:1150-1156

Hedin LO (2015) Biogeochemistry: signs of saturation in the tropical carbon sink. Nature 519:295-296

Hofmockel KS, Zak DR, Moran KK, Jastrow JD (2011) Changes in forest soil organic matter pools after a decade of elevated CO2 and 03. Soil Biol Biochem 43:1518-1527

James J, Harrison R (2016) The Effect of Harvest on Forest Soil Carbon: A Meta-Analysis. Forests 7:308

Jandl R, Lindner M, Vesterdal L, Bauwens B, Baritz R, Hagedorn F et al (2007) How strongly can forest management influence soil carbon sequestration? Geoderma 137:253-268.

Jenny H (1941) Factors of soil formation. McGraw-Hill, New York, USA

Kaiser K, Kalbitz K (2012) Cycling downwards-dissolved organic matter in soils. Soil Biol Biochem 52:29-32

Kalbitz K, Kaiser K (2008) Contribution of dissolved organic matter to carbon storage in forest mineral soils. J. Plant Nutr. Soil Sci. 171:52-60

Kitchen DJ, Blair JM, Callaham MA (2009) Annual fire and mowing alter biomass, depth distribution, and $\mathrm{C}$ and $\mathrm{N}$ content of roots and soil in tallgrass prairie. Plant Soil 323:235247

Koricheva J, Gurevitch J, Mengersen K (2013) Handbook of meta-analysis in ecology and evolution. Princeton, NJ: Princeton University Press

Koricheva J, Gurevitch J (2014) Uses and misuses of meta-analysis in plant ecology. J Ecology 102:828-844

Kuznetsova A, Brockhoff PB, Christensen RHB (2015) ImerTest: tests in linear mixed effects models. $R$ package version 2.0-29

Kuzyakov Y, Domanski G (2000) Carbon input by plants into the soil. Review. J Plant Nutr Soil Sci 163:421-431

Lajtha K, Bowden RD, Nadelhoffer K (2014a) Litter and root manipulations provide insights into soil organic matter dynamics and stability. Soil Sci Soc Am J 78:S261 
Lajtha K, Townsend KL, Kramer MG, Swanston C, Bowden RD, Nadelhoffer K (2014b) Changes to particulate versus mineral-associated soil carbon after 50 years of litter manipulation in forest and prairie experimental ecosystems. Biogeochemistry 119:341-360

Lajtha K, Bowden RD, Crow S, Fekete I, Kotroczó Z, Plante A, Simpson MJ, Nadelhoffer KJ (2018) The detrital input and removal treatment (DIRT) network: Insights into soil carbon stabilization. Sci. Total Environ. 640-641:1112-1120

Lal R (2016) Beyond COP 21: potential and challenges of the "4 per Thousand" initiative. Journal of Soil and Water Conservation 71:20A-25A

Leff JW, Wieder WR, Taylor PG et al (2012) Experimental litterfall manipulation drives large and rapid changes in soil carbon cycling in a wet tropical forest. Glob Chang Biol 18:29692979

Liebmann P, Wordell-Dietrich P, Kalbitz K, et al (2020) Relevance of aboveground litter for soil organic matter formation-a soil profile perspective. Biogeosciences Discuss. https://doi.org/10.5194/bg-2019-465, in review

Liu L, King JS, Giardina CP (2005) Effects of elevated concentrations of atmospheric CO2 and tropospheric $\mathrm{O} 3$ on leaf litter production and chemistry in trembling aspen and paper birch communities. Tree Physiol 25:1511-1522

Liu L, Wang X, Lajeunesse MJ et al (2016) A cross-biome synthesis of soil respiration and its determinants under simulated precipitation changes. Glob. Change Biol. 22:1394-1405

Lull C, Bautista I, Lidón A, del Campo AD, González-Sanchis M, García-Prats A et al (2020) Temporal effects of thinning on soil organic carbon pools, basal respiration and enzyme activities in a Mediterranean Holm oak forest. For. Ecol. Manage. 464:118088

Ma L, Guo C, Xin X, Yuan S, Wang R (2013) Effects of belowground litter addition, increased precipitation and clipping on soil carbon and nitrogen mineralization in a temperate steppe. Biogeosciences 10:7361-7372

Mathew I, Shimelis H, Mutema M, Chaplot V (2017) What crop type for atmospheric carbon sequestration: Results from a global data analysis. Agriculture, Ecosystems and Environment 243:34-46

Mathew I, Shimelis H, Mutema M, Minasny B, Chaplot V (2020) Crops for increasing soil organic carbon stocks - A global meta analysis. Geoderma 367:114230

Meyer N, Bornemann L, Welp G, Schiedung H, Herbst M, Amelung W (2017) Carbon saturation drives spatial patterns of soil organic matter losses under long-term bare fallow. Geoderma 306:89-98

Nave LE, Vance ED, Swanston CW, Curtis PS (2010) Harvest impacts on soil carbon storage in temperate forests. For Ecol Manage 259:857-866

Paterson E, Sim A, Osborne SM, Murray PJ (2011) Long-term exclusion of plant-inputs to soil reduces the functional capacity of microbial communities to mineralise recalcitrant rootderived carbon sources. Soil Biol Biochem 43:1873-1880

Percival HJ, Parfitt RL, Scott NA (2000) Factors Controlling Soil Carbon Levels in New Zealand Grasslands: Is Clay Content Important? Soil Sci Soc Am J 64:1623-1630 
Raich JW, Russell A, Kitayama K, Parton WJ, Vitousek PM (2006) Temperature influences carbon accumulation in moist tropical forests. Ecology 87:76-87

Rasse DP, Rumpel C, Dignac MF (2005) Is soil carbon mostly root carbon? Mechanisms for a specific stabilisation. Plant Soil 269:341-356

Rumpel C, Chabbi A, Marschner B (2012) Carbon storage and sequestration in subsoil horizons: Knowledge, gaps and potentials. In: Recarbonization of the Biosphere (pp. 445-464). Springer

Stewart CE, Paustian K, Conant RT, Plante AF, Six J (2007) Soil carbon saturation: concept, evidence and evaluation. Biogeochemistry 86:19-31

Sayer EJ (2006) Using experimental manipulation to assess the roles of leaf litter in the functioning of forest ecosystems. Biol Rev 81:1-31

Sayer EJ, Baxendale C, Birkett AJ, Bréchet LM, Castro B, Kerdraon-Byrne D, ... \& Rodtassana C (2020) Altered litter inputs modify carbon and nitrogen storage in soil organic matter in a lowland tropical forest. Biogeochemistry, in press.

Sayer EJ, Heard MS, Grant HK, Marthews TR, Tanner EVJ (2011) Soil carbon release enhanced by increased tropical forest litterfall. Nat Clim Change 1:304-307

Sayer EJ, Lopez-Sangil L, Crawford JA et al (2019) Tropical forest soil carbon stocks do not increase despite 15 years of doubled litter inputs. Sci Rep, accepted.

Sayer EJ, Tanner EVJ (2010) Experimental investigation of the importance of litterfall in lowland semi-evergreen tropical forest nutrient cycling. J Ecol 98:1052-1062

Six J, Conant RT, Paul EA, Paustian K (2002a) Stabilization mechanisms of soil organic matter: Implications for C-saturation of soils. Plant Soil 241:155-176

Six J, Feller C, Denef K, Ogle SM, de Moraes Sa JC, Albrecht A (2002b) Soil organic matter, biota and aggregation in temperate and tropical soils-Effects of no-tillage. Agronomie 22: 755775

Swift MJ, Heal OW, Anderson JM, Anderson JM (1979) Decomposition in terrestrial ecosystems. Blackwell Scientific Publications

Tanner EVJ, Sheldrake MWA, Turner BL (2016) Changes in soil carbon and nutrients following 6 years of litter removal and addition in a tropical semi-evergreen rain forest. Biogeosciences 13:6183-6190

Ugarte CM, Kwon H, Andrews SS, Wander MM (2014) A meta-analysis of soil organic matter response to soil management practices: An approach to evaluate conservation indicators. J Soil Water Conserv 69:422-430

van den Noortgate W, Onghena P (2005) Parametric and nonparametric bootstrap methods for meta-analysis. Behavior Research Methods 37:11-22

Viechtbauer W (2005) Bias and efficiency of meta-analytic variance estimators in the randomeffects model. J Educ Behav Stat 30:261- 293

Viechtbauer W (2010) Conducting meta-analyses in R with the metafor package. J Stat Softw 36:1-48

Wang Y, Zhang C, Zhang G, Wang L, Gao Y, Wang X, Liu B, Zhao X, Mei H (2019) Carbon input manipulations affecting microbial carbon metabolism in temperate forest soils-A 
comparative study between broadleaf and coniferous plantations. Geoderma 355:113914

Xia J, Wan S (2008) Global response patterns of terrestrial plant species to nitrogen addition. New Phytol 179:428-439

Xu S, Liu LL, Sayer EJ (2013) Variability of above-ground litter inputs alters soil physicochemical and biological processes: a meta-analysis of litterfall-manipulation experiments. Biogeosciences 10:7423-7433

Xu S, Li P, Sayer EJ et al (2018) Initial Soil Organic Matter Content Influences the Storage and Turnover of Litter, Root and Soil Carbon in Grasslands. Ecosystems 21:1377-1389

Zech W Senesi N, Guggenberger G et al (1997) Factors controlling humification and mineralization of soil organic matter in the tropics. Geoderma 79:117-161.

Zhang D, Hui D, Luo Y, Zhou G (2008) Rates of litter decomposition in terrestrial ecosystems: global patterns and controlling factors. J Plant Ecol 1:85-93

Zhao M, Running SW (2010) Drought-induced reduction in global terrestrial net primary production from 2000 through 2009. Science 329:940-943

Zhao Q, Classen AT, Wang WW, Zhao XR, Mao B, Zeng DH (2017) Asymmetric effects of litter removal and litter addition on the structure and function of soil microbial communities in a managed pine forest. Plant Soil 414:81-93

Zhou GY, Wei XH, Chen XZ et al. Global pattern for the effect of climate and land cover on water yield. Nat. Commun.2015; 6, 5918.

Zhou G, Xu S, Ciais P et al (2019) Climate and litter C/N ratio constrain soil organic carbon accumulation. Natl Sci Rev 6:746-757 
Table 1 Effects of litter removal and litter addition on soil carbon (C) stocks $\left(\mathrm{kg} \mathrm{m}^{-2}\right)$ at different soil layers $(0-5,5-20,0-10,0-20$ and 20-100 $\mathrm{cm})$ in different ecosystems (grassland, natural forest, plantation and cropland). For each response variable, significant changes in soil $\mathrm{C}$ stocks at each depth increment are shown in bold font. RR is the mean log response ratio, whereby values $>1$ indicate an increase and values $<1$ indicate a decline; $\mathrm{Cl}$ is confidence interval; $n$ is the number of observations included in the analyses and a dash indicates insufficient data.

\begin{tabular}{|c|c|c|c|c|c|c|c|c|c|c|c|c|}
\hline \multirow[b]{2}{*}{ Variable } & \multirow[b]{2}{*}{ Ecosystem } & \multirow[b]{2}{*}{ Soil layer $(\mathrm{cm})$} & \multirow[b]{2}{*}{ RR } & \multicolumn{5}{|c|}{ Litter removal } & \multicolumn{4}{|c|}{ Litter addition } \\
\hline & & & & lower $\mathrm{Cl}$ & upper $\mathrm{Cl}$ & $n$ & $p$ & $\mathrm{RR}$ & lower $\mathrm{Cl}$ & upper $\mathrm{Cl}$ & $n$ & $p$ \\
\hline \multirow{20}{*}{$\begin{array}{l}\text { Soil C stock } \\
\left(\mathrm{kg} \mathrm{m}^{-2}\right)\end{array}$} & grassland & $0-5$ & -- & -- & -- & -- & -- & -- & -- & -- & -- & -- \\
\hline & & $5-20$ & -- & -- & -- & -- & -- & -- & -- & -- & -- & -- \\
\hline & & $0-10$ & -0.214 & -0.372 & -0.057 & 5 & 0.018 & & & & & \\
\hline & & $0-20$ & -- & -- & -- & -- & -- & -- & -- & -- & -- & -- \\
\hline & & $20-100$ & -- & -- & -- & -- & -- & -- & -- & -- & -- & -- \\
\hline & $\begin{array}{l}\text { natural } \\
\text { forest }\end{array}$ & $0-5$ & -0.218 & -0.338 & -0.099 & 14 & 0.002 & -- & -- & -- & -- & -- \\
\hline & & $5-20$ & -- & -- & -- & -- & -- & 0.114 & -0.183 & 0.411 & 3 & 0.310 \\
\hline & & $0-10$ & -0.290 & -0.431 & -0.148 & 10 & 0.001 & 0.059 & -0.044 & 0.162 & 11 & 0.236 \\
\hline & & $0-20$ & -- & -- & -- & -- & -- & -- & -- & -- & -- & -- \\
\hline & & $20-100$ & -- & -- & -- & -- & -- & -- & -- & -- & -- & -- \\
\hline & plantation & $0-5$ & -0.086 & -0.244 & 0.073 & 3 & 0.185 & -0.028 & -0.152 & 0.096 & 3 & 0.523 \\
\hline & & $5-20$ & -0.120 & -0.245 & 0.006 & 9 & 0.059 & 0.014 & -0.057 & 0.084 & 6 & 0.656 \\
\hline & & $0-10$ & & & & & & -- & -- & -- & -- & -- \\
\hline & & $0-20$ & -0.246 & -0.870 & 0.378 & 4 & 0.335 & & & & & \\
\hline & & $20-100$ & -0.139 & -0.367 & 0.089 & 3 & 0.148 & -- & -- & -- & -- & -- \\
\hline & cropland & $0-5$ & -0.321 & -0.559 & -0.083 & 4 & 0.020 & -- & -- & -- & -- & -- \\
\hline & & $5-20$ & -0.258 & -0.385 & -0.131 & 15 & 0.001 & -- & -- & -- & -- & -- \\
\hline & & $0-10$ & -0.167 & -0.352 & 0.018 & 6 & 0.070 & -- & -- & -- & -- & -- \\
\hline & & $0-20$ & -0.134 & -0.236 & -0.032 & 18 & 0.013 & -- & -- & -- & -- & -- \\
\hline & & $20-100$ & -0.388 & -0.726 & -0.051 & 5 & 0.032 & -- & -- & -- & -- & -- \\
\hline
\end{tabular}


Figure 1 Diagram summarizing the effects of altered aboveground plant litter inputs, including litter removal or addition treatments and management practices related to varied aboveground litter inputs, on soil carbon storage at different depths $(0-5 \mathrm{~cm}, 5-20 \mathrm{~cm}, 0-10$ $\mathrm{cm}, 0-20 \mathrm{~cm}, 20-100 \mathrm{~cm}$ ).

\section{Variations in above-ground litter inputs}
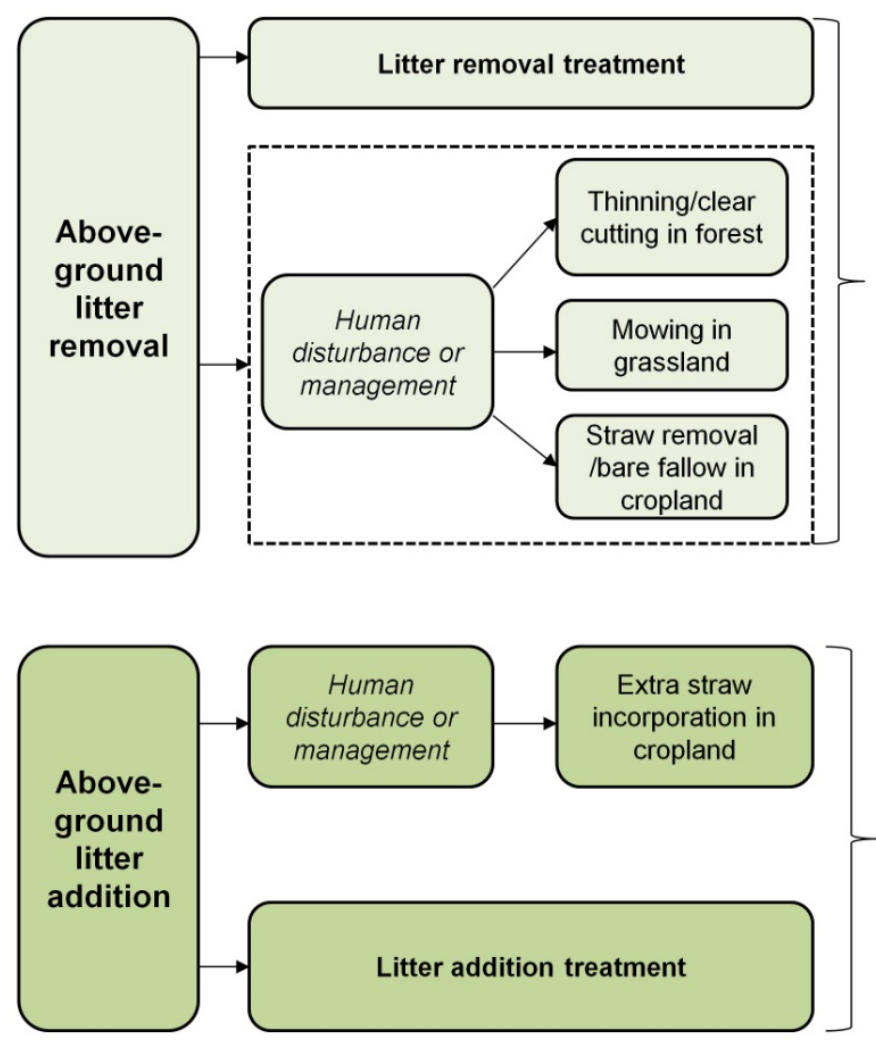

$(-)$

\section{Below-ground Carbon Storage}

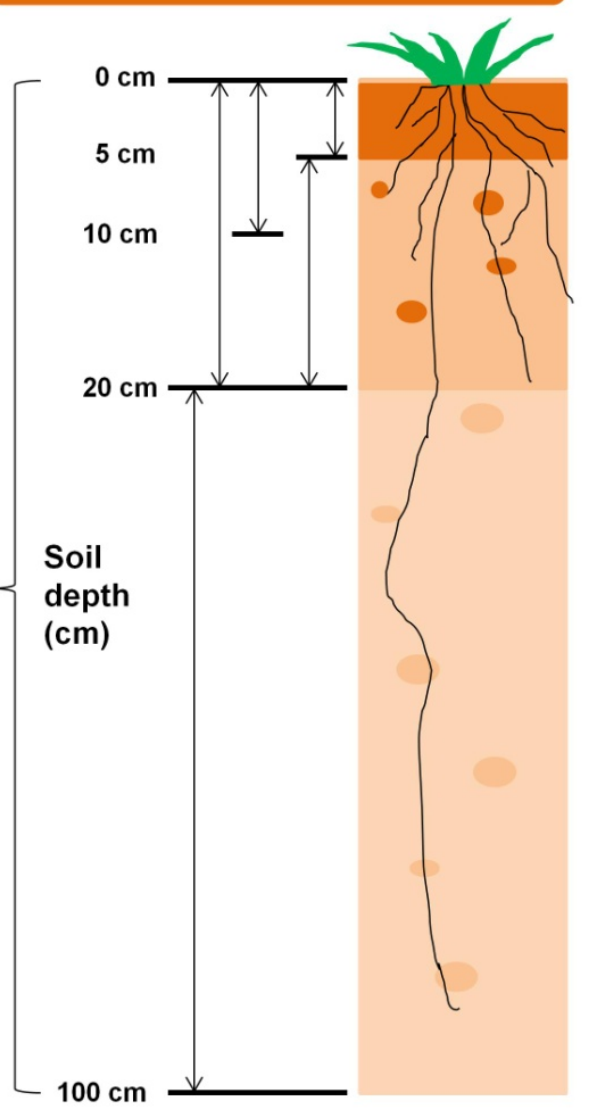


Figure 2 Changes in soil carbon (C) content and stocks at different depth increments $(0-5 \mathrm{~cm}$, 5-20 cm, 0-10 cm, 0-20 cm, 20-100 cm) in response to (a) litter removal and (b) litter addition. Effect sizes are given as mean weighted log response ratios (RR) for $n$ studies per response variable and error bars represent $95 \%$ confidence intervals; an effect size of 0 (dashed line) indicates no change relative to controls, and values $>0$ or $<0$ indicate an increase or decrease, respectively. Numbers in parentheses represent the number of observations $(n)$ for each parameter. "***" indicates $P<0.0001 ; " * * "$ indicates $P<0.001$; $" *$ " indicates $P<0.05$; "." indicates $0.05<P<0.1$

(a) Litter removal

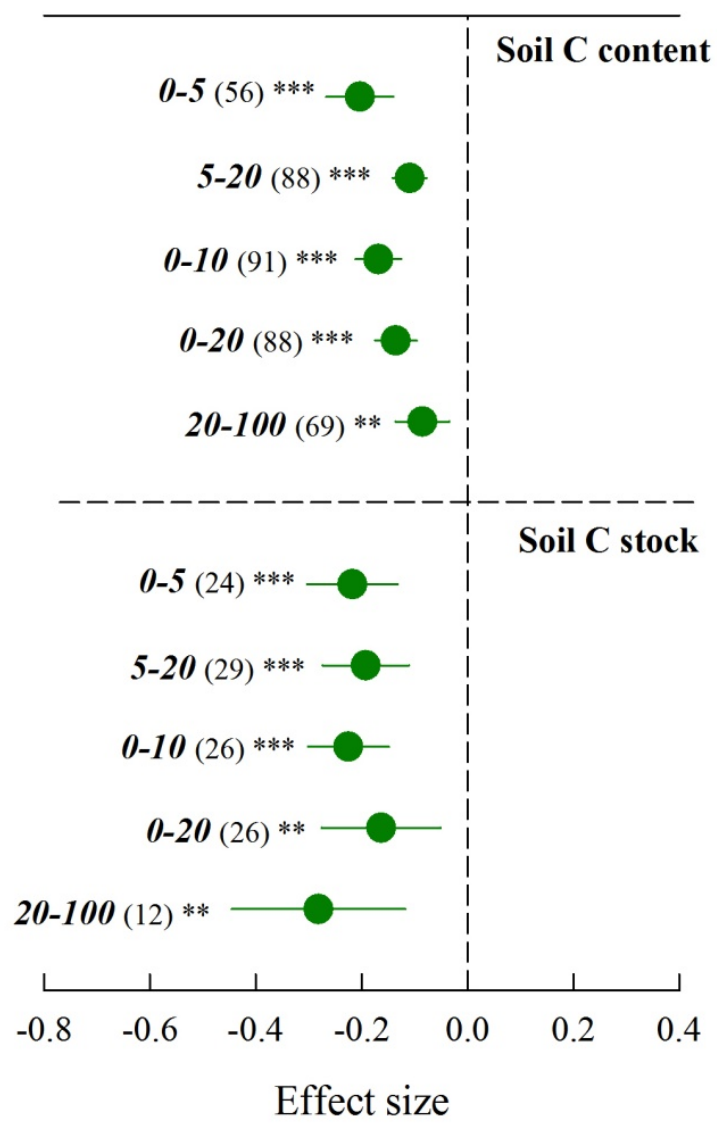

(b) Litter addition

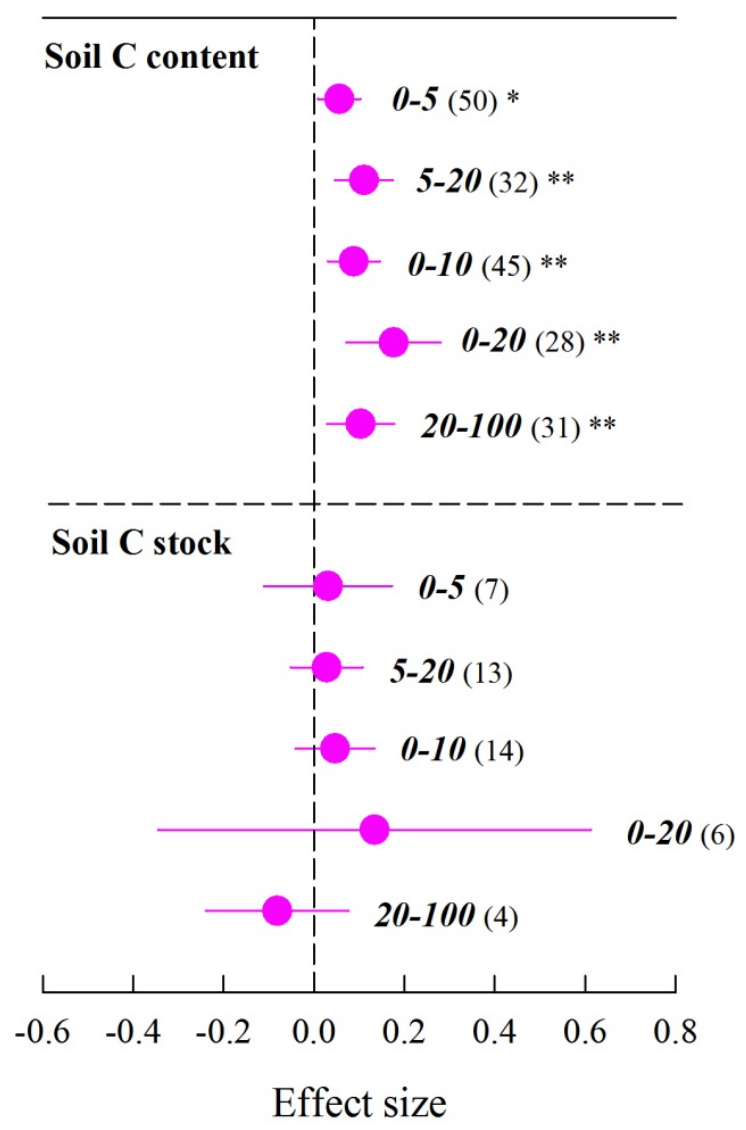


Figure 3 Changes in soil carbon (C) content and stocks at different depth increments $(0-5 \mathrm{~cm}$, $5-20 \mathrm{~cm}, 0-10 \mathrm{~cm}, 0-20 \mathrm{~cm}, 20-100 \mathrm{~cm}$ ) in response to (a) litter removal and (b) litter addition across different ecosystems, i.e. grassland, natural forest, plantation and cropland. Effect sizes are given as mean weighted log response ratios (RR) for $n$ studies per response variable and error bars represent 95\% confidence intervals; an effect size of 0 (dashed line) indicates no change relative to controls, and values $>0$ or $<0$ indicate an increase or decrease, respectively. Numbers in parentheses represent the number of observations $(n)$ for each parameter. "***" indicates $P<0.0001 ; " * * "$ indicates $P<0.001$; "*" indicates $P<0.05$; "." indicates $0.05<P<0.1$.

\section{(a) Litter removal}

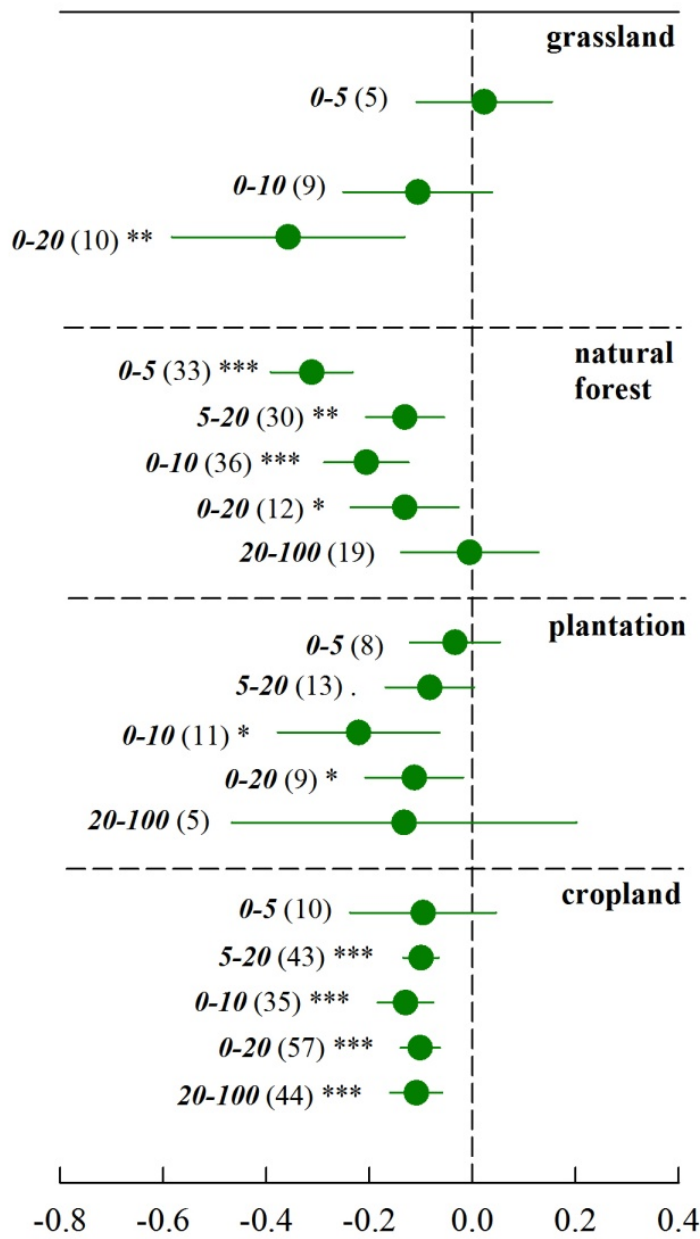

Effect size

\section{(b) Litter addition}

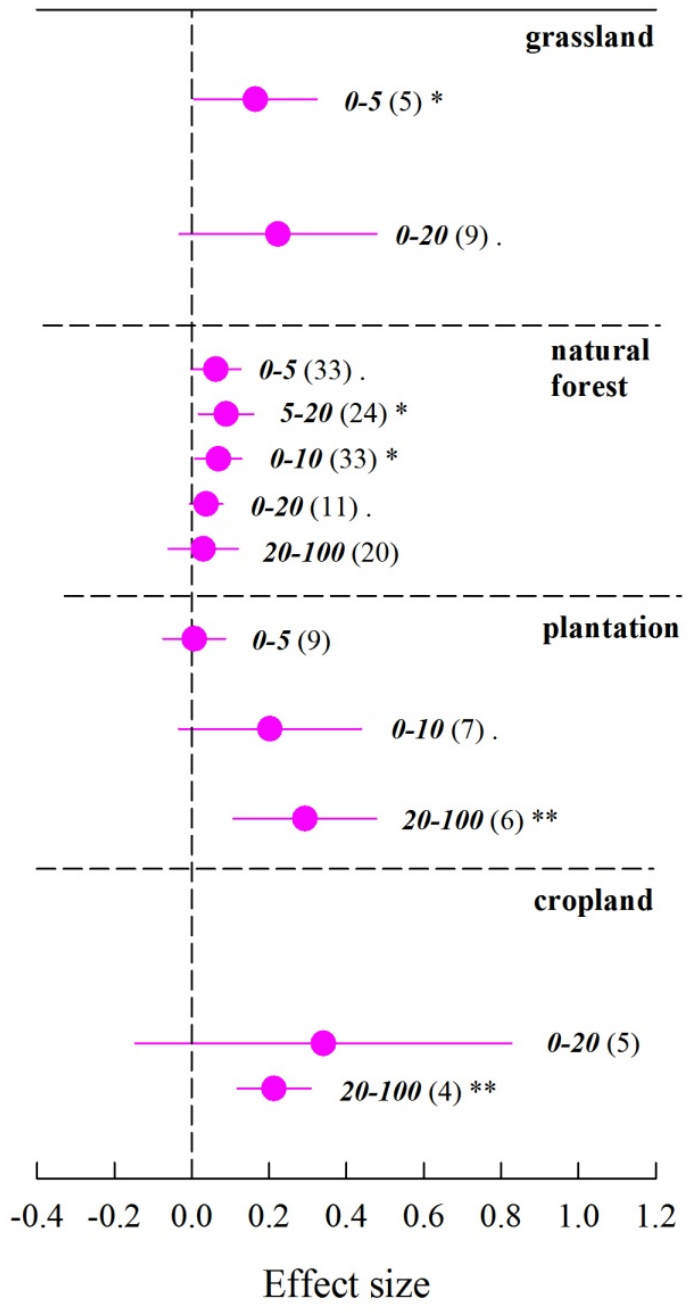


Figure 4 Relationships between the change in soil carbon (C) content across soil profiles and treatment levels $\left(\mathrm{g} \mathrm{m}^{-2} \mathrm{yr}^{-1}\right.$ ) of litter manipulation: (a) $0-5 \mathrm{~cm}$ in grassland, (b) $0-20 \mathrm{~cm}$ in grassland, (c) 0-5 cm in natural forest, (d) $5-20 \mathrm{~cm}$ in natural forest, (e) $0-10 \mathrm{~cm}$ in natural forest, (f) $0-20 \mathrm{~cm}$ in natural forest, (g) $20-100 \mathrm{~cm}$ in natural forest, (h) $0-5 \mathrm{~cm}$ in plantation, (i) 0-10 cm in plantation, (j) $20-100 \mathrm{~cm}$ in plantation, (k) 0-20 cm in cropland, (I) $20-100 \mathrm{~cm}$ in cropland. Changes are given as log response ratios (RR) relative to controls for individual studies. $R^{2}$ values and regression lines are shown for significant relationships at $P<0.05$.
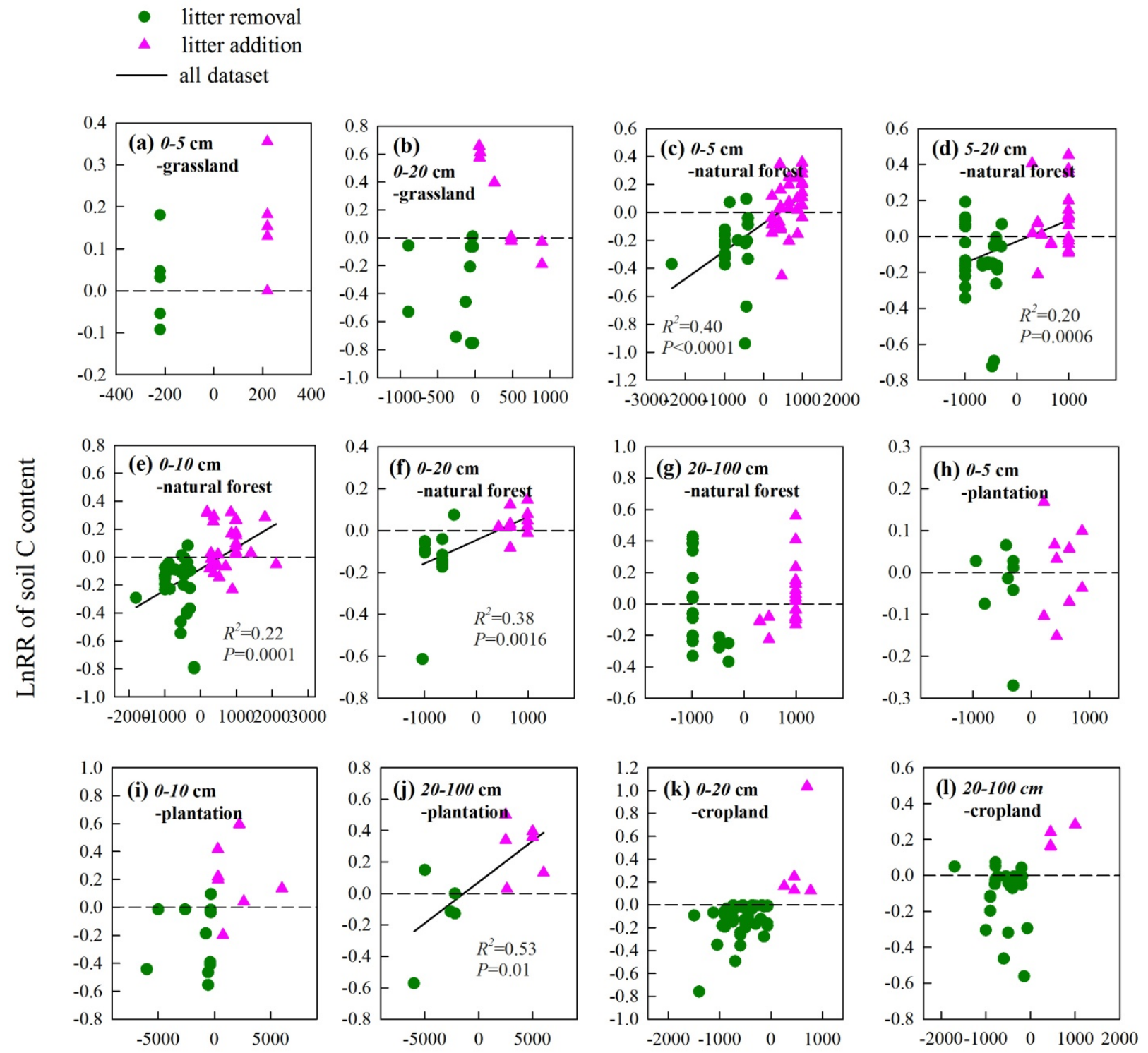

Aboveground litter inputs ( $\mathrm{g}$ dry mass $\left.\mathrm{m}^{-2} \mathrm{yr}^{-1}\right)$ 
Figure 5 Relationships between changes in soil carbon (C) content in response to litter removal and litter addition at different depth increments $(0-5 \mathrm{~cm}, 5-20 \mathrm{~cm}, 0-10 \mathrm{~cm}, 0-20 \mathrm{~cm}$, 20-100 cm) and treatment duration (in years) across ecosystems. Changes are given as log response ratios (RR) relative to controls for individual studies. $R^{2}$ values and regression lines are shown for significant relationships at $P<0.05$.
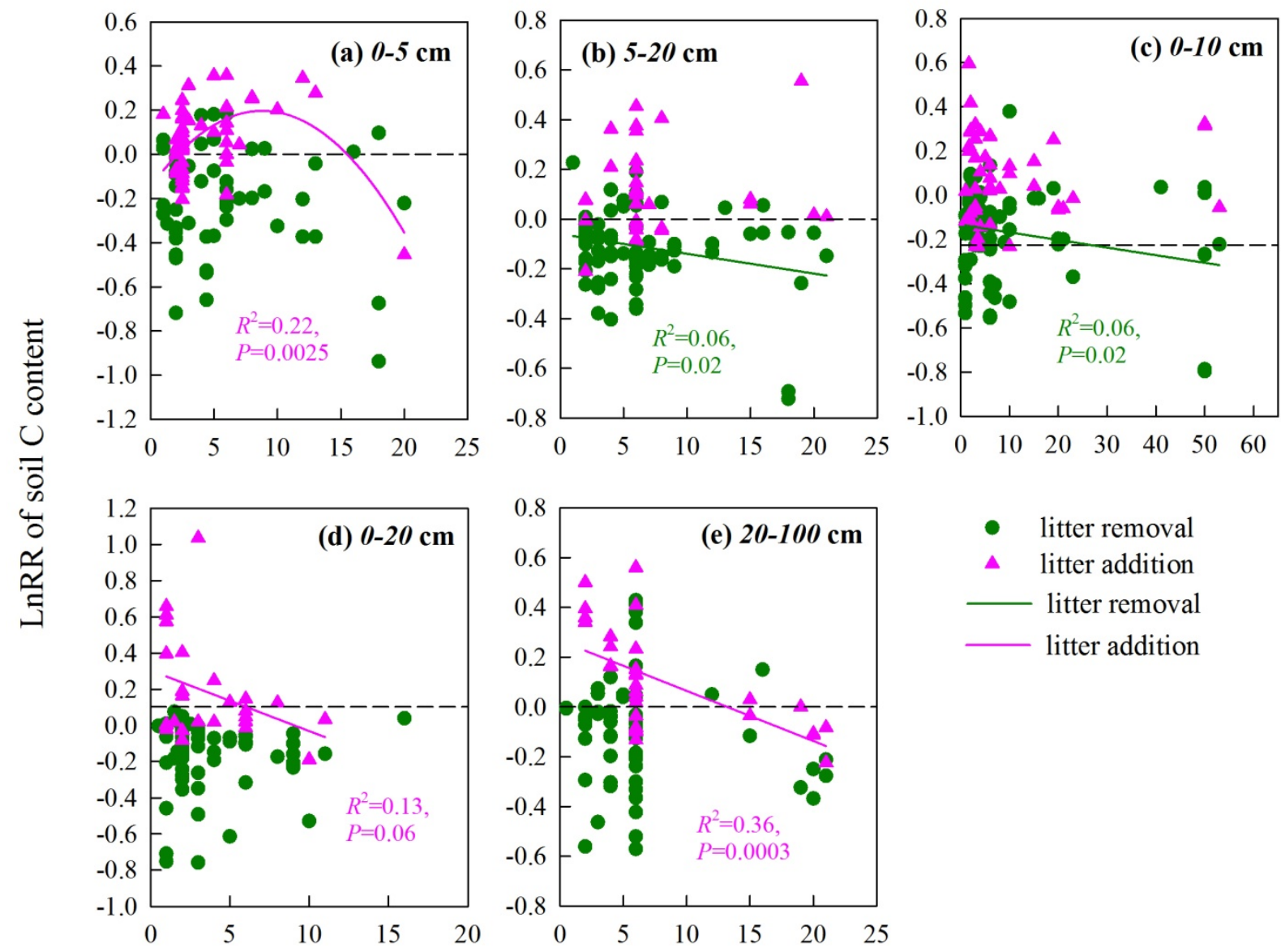

- litter removal

- litter addition

- litter removal litter addition

Experimental duration (year) 
Figure 6 Relationships between changes in soil carbon (C) content in response to litter removal and litter addition at different depth increments $(0-5 \mathrm{~cm}, 5-20 \mathrm{~cm}, 0-10 \mathrm{~cm}, 0-20 \mathrm{~cm}$, 20-100 cm) and the wetness index across ecosystems under litter removal and litter addition. Changes are given as log response ratios (RR) relative to controls for individual studies. $R^{2}$ values and regression lines are shown for significant relationships between at $P<0.05$.
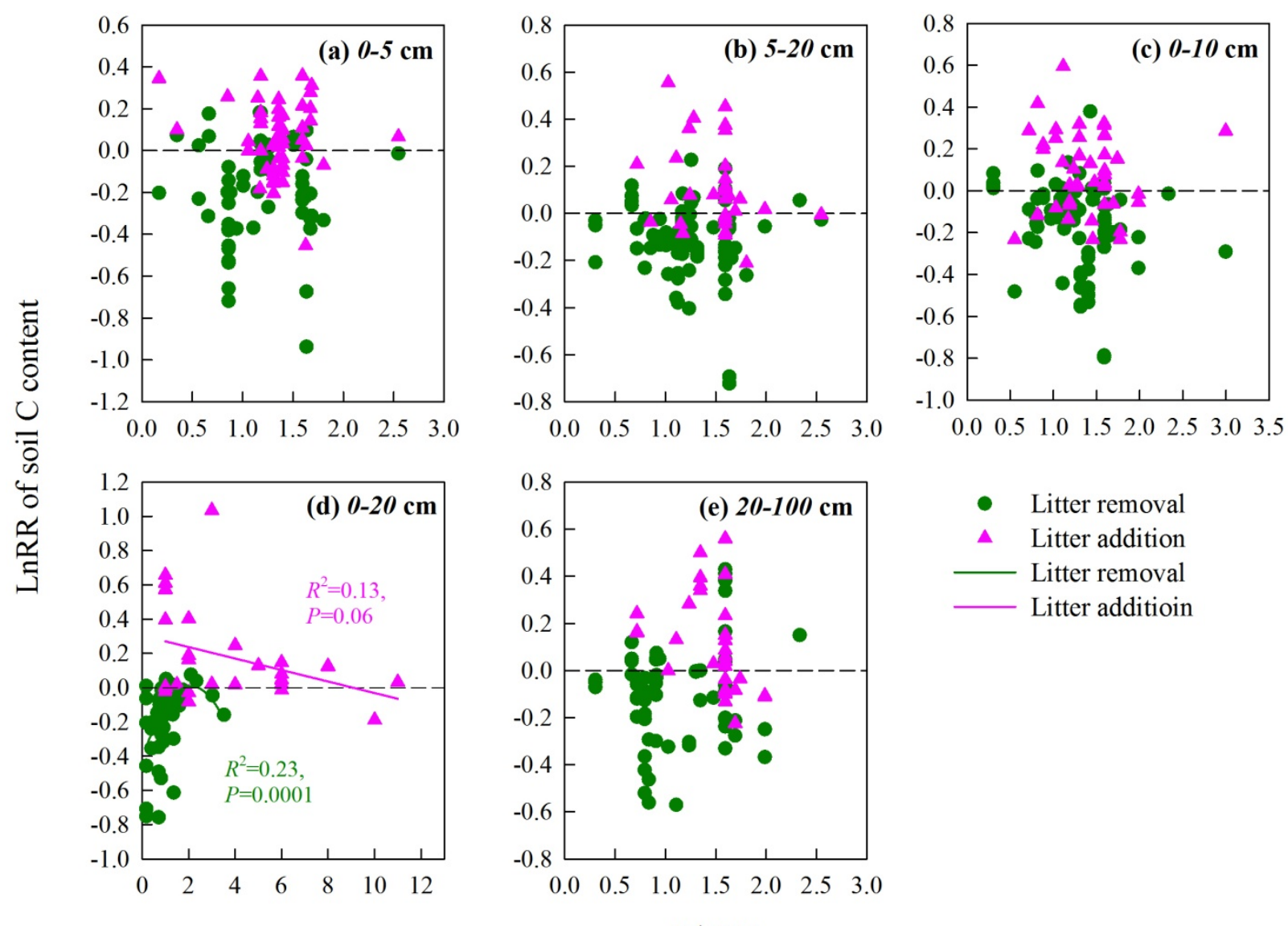

- Litter removal

- Litter addition - Litter removal Litter additioin

P/PET 